\title{
Examining the Usage of City Walls for Wall Chalking: Cases from Karachi, Pakistan
}

\author{
Noman Ahmed ${ }^{1}$ and Suneela Ahmed ${ }^{*}$ \\ ${ }^{1}$ NED University of Engineering \& Technology, Karachi, Pakistan
}

\begin{abstract}
External walls and facades of buildings are commonly exposed elements in urban built environments. These structures are also used as a means of communication by different stakeholders for cultural, religious, commercial, political, welfare and promotion of public art. It is generally considered as an illegal enterprise in many urban contexts. However, wall chalking continues to exist and expand as an alternative medium of communication. This paper questions the paradox of legal prohibition versus continued existence of wall chalking and the reasons behind its continued practice. Various forms of wall chalking are looked into, ranging from populist messages, commercial announcements and some art work. The paper probes into the various formats of this peculiar visual enterprise for examining its social, cultural and political justification or otherwise, as subscribed by the related stakeholders, within the paradigm of various types of informal practices within the city, and how these informal practices are viewed with respect to, so called 'formal' ways of doing things. Six public locations in Karachi were chosen as case study areas for in-depth appraisal into the phenomenon. Silent observations of the locations, photographic documentation of wall chalking and graffiti and in-depth interviews of identified stakeholders have been used as tools for gathering information.
\end{abstract}

Keywords: Alternative Communication, City Walls, Informal Practices, Karachi, Wall Chalking

\section{Introduction}

Wall chalking is defined in multiple ways. From a statutory perspective, it is viewed as an undesirable feat that merits prohibition. In United Kingdom, Anti-Social Behavioural Act 2003 defines graffiti as 'painting, writing, soiling, marking or other defacing by whatever means'. It is illegal and the perpetrator can be subjected to fine and prosecution (CathcartKeays, 2015). Laws in Pakistan echo similar sentiments. In Sindh province, wall chalking and graffiti is placed in the definition of 'defacement'. Interfering in the appearance of property, damaging, disfiguring, spoiling, writing, affixing material or performing any such act which results in loss of aesthetics is categorized as defacement (Government of Sindh, 2014). This enterprise is also defined as transgressive, as it is done in defiance of standing laws but often with objectives to benefit a public cause (Seloni and Sarfati, 2017).
All of these statutes are based on protecting property rights of private and public owners, maintaining a certain level of urban aesthetics in a pristine form, disallowing anti-social and undesirable political communication and out lawing urban anarchy.

The Merriam Webster Dictionary defines graffiti as 'unauthorized writing or drawing on a public surface', whereas the Cambridge English Dictionary defines it as 'words or drawings, especially humorous, rude, or political, on walls, doors, etc. in public places'. The aspects of authority and public spaces become the key points of consideration, because if these words or drawings are scribbled in private places, then the question of graffiti as a legal or illegal act does not arise. In order to determine whether a certain act is legal or illegal, the process through which it comes into existence becomes a measure, so formal processes are usually termed legal and informal 
processes which are not supported through statuary rules and regulations are termed illegal. This paper focuses on wall chalking, a particular type of graffiti, and the stand point reviewed and analysed is that it is an alternate means of communication, an informal urban process patronized by local processes/agencies and reflecting particular social, economic and political processes, in the context of Karachi. The reason for focusing on wall chalking in particular is because graffiti as pop art or other forms is non-existent in the city. Furthermore, most of the international literature is on typology of graffiti (Palmer, 2017), its role in reflecting political (Gilmore, 2012) and social issues (McAuliffe \& Iveson, 2011) and the debate about ownership of public spaces (Bacharach, 2015) which leads to a certain view about graffiti. There is dearth of knowledge, research and studies with regards to wall chalking or other forms of graffiti within Pakistan, and in Karachi in particular (Mahmood, Saleem, \& Baig, 2005).

This research, within the larger paradigm of co-existence of formal and informal enterprises, analysis and questions the contradiction between the legal prohibition of graffiti and its continued existence, and the reasons behind its practice. The manuscript has documented various forms of wall chalking and sociopolitical reasons behind that work. The methodology used for this paper is largely based on documentation and in depth appraisal of wall chalking done in six public locations in Karachi. These locations were strategically chosen, the wall chalking done in these locations was recorded and tabulated over a period of time, it was done analysed with respect to various messages and political, social and economic connotations. This documentation was coupled with twenty-five in-depth interviews of populist artists, informal service providers, representatives of political parties, city administration staff, passers-by and members of overt and covert groups that subscribe to wall chalking. This was coupled with silent observations of the localities and photographic documentation of these wall chalking between January to November 2018. The results point towards the continued practice of this form of communication in the context of Karachi, mainly because of lack of alternate outlets for conveying these messages. Sometimes, this practice is turned on a blind eye by the police and other officials, because either they silently support the messages being put across or are informally taken into confidence by the prescribers of this activity. But most of the political parties support this activity as it acts a vital means of communication with party workers, and for general dissemination of knowledge, thus the activity continues.

\section{Literature Review}

Graffiti, in general is seen as reflection of a particular culture and aspirations of a society (Castellón, 1978; Cohan, 1975; Freeman, 1966). Furthermore, all forms of this expression are informal (or alternative) means of communication which are applied in different ways. Contemporary graffiti is also known to have a deep connection with specific cultures being studied (Mahmood, Saleem, \& Baig, 2005). Some cultures are more tolerant towards this form of expression, whereas others may have a different stand point. (Menor, 2015) mentions the principle of "broken windows" (Menor, 2015:62) with respect to governance of public spaces by local governments and having no tolerance towards public expression in the form of graffiti or wall chalking. This principle is based on Wilson and George Kelling's theory published in 1982 (William \& Kelling, 1982), about how disorder of any kind becomes a seed for germinating more serious crime, if it is not curbed in its infancy, and the term 'broken windows' is taken as a metaphor towards this end (Menor, 2015). This raises questions of governance, and contraction in the way certain street art is on one hand seen as a menace and on the other hand promoted and even patronized, where as wall chalking is generally seen as undesirable. "Indeed graffiti under this approach, would contribute to the physical degradation of a given space and, therefore, be a clear example of disorder" (Menor, 2015, p. 62).

A wall, which by its existence in a public space, should be denoted by equal ownership by the public (Klein, 2000) but is claimed by hegemonic forces, and any expression by the public on these walls, in principle is controlled. This ties up with the concept of contestation of public space, who owns it, who controls it, is it a collective good and does it have a sense of belonging and any meaning associated with it? "Depending on how public spaces are conceived, the walls which define these spaces, reflect dialectical and dialogical exchanges across stakeholders" (Visconti, Jr., Borghini, \& Anderson, 2010, p. x) in the form of graffiti.

The notion of ownership of public spaces within an urban setting and the idea of it being 
a collective good, is tied up with the notion of flexibility offered in an informal space, because of weak bye laws and rules governing them, and because of unclear/ weak mechanisms of control. According to Simone and Pieterse (2017), who have documented and analysed the ways in which people perform in various urban settings to uphold or outspread livings, these practices are usually associated with the informal sector of the city, thus they are not recognized by the formal agencies as they may not fit within the prescribed nature of the formal sector practices and may be out of the box too. They point towards these out of box practices as examples of complex relationships between different actors performing at various scales, within the complex whole, known as the city. Wall Chalking, as a form of graffiti, is one such practice and must be researched and analysed from the lens of an alternate means of communication, rather than an undesired/ unwarranted practice. (Simone \& Pieterse, 2017).

Furthermore, this informal practice should not simply be viewed as the opposite of the formal, or the "other of the formal city" as many "developed cities can be infused by high level of informality" (Dovey, 2012, p. 352). The comprehension of this informality helps decode the various actors and their crucial roles within the socio-spatial setups, at grass root levels, as the knowledge about community setups can help improve "liveability and social cohesion in disadvantaged and heterogeneous urban settings" (Wekker, 2017, p. 9). This understanding can in-turn aid policy makers, sociologists, anthropologists and other professionals involved with the study of the built form, in some way or another. Seen from a dogmatic point of view, communal cohesion, feelings of belonging and social engagement are seen as essential ingredients in an urban neighbourhood. Hansen \& Verkaaik (2009), argue that through reading cities through 'performative spaces', spaces which are decoded through repetitive flows of accounts about 'us' and 'them', can give insight into a number of social, political and economic processes, which are otherwise difficult to pinpoint. Public spaces which exhibit examples of wall chalking as examples of such spaces of performance, within the public realm (Hansen \& Verkaaik, 2009).

If seen within the above mentioned debates of formality and informality, Zukin (1998)'s work further facilities the understanding of street art, within the landscape of power, its production and different attempts in which authorities manage public spaces. This leads to the question of viewing graffiti as art, or crime, based on social and political repercussions it can create (Zukin, 1998).

Reasons for conducting wall chalking are several. It is done as a means of extending information on a variety of subjects to ordinary masses. Wall chalking is also done for protest and alternative political communication. It is often practiced for promoting cultural and religious messages, hurling hate on political or religious opponents. It is also carried out to convey public mood and voices of silent population around pressing political issues. Warsaw, during the fall of iron curtain and after, was simmering with political and social transformation. Many labyrinths of undercurrents of this happening phase of the Polish political moods were depicted through wall chalking, popular arts and graffiti on the city walls (Chmielewska, 2005). Dahdal (2017) conducted an exhaustive study on the Bethlehem wall from the Palestinian side. Many graffiti artists used their artistic acumen to paint the Palestinian perspective in a skilful manner. Among other aspects, the key messages commonly observed in these compositions included the invitation to lasting peace, figurative depictions of various communities in Palestine and pointed criticism towards global leaders visiting the other side of the wall. A wall note also showed that graffiti is capable to give voice to the voiceless (Dahdal, 2017). Srivathsan, Samuel, Pandian, \& Radhakrishnan, 2010 illustrated the many faces of Chennai in India as depicted in graffiti upon varied surfaces. Plurality of urban scenes, under currents and characters are displayed on walls and surface as artefacts. Georgion, 2009 found youth as a major subscriber of graffiti to vent their aspirations, feelings and dreams. The language, content and syntax is often in defiance and deviation from the conventions of the society. He cited examples from Denmark, Turkey, Estonia and many other European contexts. In West Africa, like many other parts of the world, graffiti has been practiced in an imaginative manner by folk artists for a variety of purposes. Expressions of traditional knowledge, means of education and advice are some of the purposes served by skilful application of graffiti (Obiozer, 2008). Le Vine (2015) narrates the role of wall chalking and graffiti in the Arab spring. At the onset, Tahrir Square in Cairo became a hub of intense revolutionary activity with graffiti playing a 
major role in communicating the public mood to all the onlookers. Alongside many formats of social media were used to keep connected with the expected wave of political change. In comparison to other art forms, graffiti had a powerful presence for its all-round visibility and physical scale. Seloni \& Sarfati (2017) documented and analysed the usage of street art and graffiti from the Gezi Park episode in Istanbul during 2013. A creative use of this art form and technique helped galvanize the protesters who were resisting a government move to convert a segment of historic urban landscape into a commercial space. The ensuing police brutality on the protesters became a subject of chalking messages.

Distinct cultural reflections are often displayed through an extensive use of graffiti. China towns in western urban contexts display the cultural entity of their residents through signage, billboards, cultural hoardings and buntings (Lou, 2007). The public squares, train stations, tube / metro junctions, congregation spots, campus walls, movement corridors, pedestrian precincts, terminals and market places are few locations in cities where graffiti, wall chalking and other forms of populist communications are commonly found. Many contexts have well laid down regulations and guide lines for managing graffiti. In Sydney, a distinction is drawn between illegal graffiti and legal street art. The former is done without lawful permission of the owner, while the latter is conducted with the express sanction of the owner (City of Sydney, 2018). In several cities in the developing countries, wall chalking and graffiti is subjected to strict administrative scrutiny. Karachi in Pakistan is an interesting case example in the same respect.

Conclusively, "graffiti is certainly visible all too visible, according to those who want it eradicated. But is graffiti a form of public address, if we think about publicness as a form of collectively?" (Cathecart-Keays, 2015). There is no debate that graffiti, in all its ways of expression, surpasses formal norms applicable to urban spaces, and is an exhibition of suppressed voices at times, or of aspirations which do not find other mediums of expression, it writes its own story and also leads to commodification of public spaces, as it can appear on private property facing public streets. "These distinctive geographies of graffiti challenge us to clarify distinctions between public and private, between legitimate and illegitimate expression, between legal and illegal activities in the city, between art and crime" (McAuliffe \& Iveson, 2011). Karachi, the chosen context of this paper, offers many interesting evidences of the issues discussed above.

\section{Research Methodology}

Silent observations and photographic documentation of walls and external building facades along the streets was done during day time on weekly holidays between January to November 2018. A total of 25 in-depth interviews were carried out with several categories of stakeholders including populist artists, informal service providers, representatives of political parties, city administration staff, passers-by and members of overt and covert groups that subscribe to wall chalking to inform the common public on various counts. The stakeholders responded to questions and queries of the author only on the condition of absolute anonymity (Refer Table 1). Qualitative research methods were followed including visual documentation of the subject matter, silent observations of wall chalking and graffiti, review of records and material related to wall chalking and graffiti and interviews with stakeholders. Silent observations helped document the various messages put on the walls of the city, in different areas. These messages were then tabulated according to their content and the locations where they were noticed. A relationship and analysis was then made, and written up which informs this paper. The silent observations also helped to counter check the findings of the qualitative interviews of different stakeholders, and thus lead to triangulation of the data.

\section{The Context}

Karachi is the largest city of Pakistan with a cosmopolitan population and complex political culture. It is a city of contrasts with most affluent neighbourhood en-whorled by squatter hutments and service settlements, where both the formal and informal sectors work hard to provide various basic facilities related to urban living. This research, within the larger paradigm of co-existence of formal and informal enterprises, analysis and questions the contradiction between legal prohibition of graffiti and its continued existence, and the reasons behind its practice. As a result, various forms of wall chalking are documented and analysed to bring out the social, cultural and 
political justification, as subscribed by the different stakeholders.

The graffiti and wall chalking on external surfaces offered an option for expression. As political dissenters are often scared of openly communicating views that the ruling regime and military establishment may despise, such hard hitting opinions are spread through wall chalking. Since the political and social conduct of the institutions and society is not changing to accommodate dissent, the graffiti and wall chalking continues on.

Administratively, the city comprises of six districts namely South, Central, Malir, Korangi, East and West. 2017 census informed that Karachi has a population of over 16 million people. The city is the economic and financial capital of Pakistan. It contributes 15 percent of the GDP and accounts for 25 percent of federal revenue (World Bank, 2018). It is the location of the only two functional ports and busiest international airport in the country. It also accounts for an expanded informal sector that sustains employment for more than half of the city dwellers. Political, cultural, religious and ethnic frictions have been routinely observed as ingredients of the city's social and political life. In many cases, various political, ethnic, religious and social/cultural groups found constrained to express themselves through mainstream media or communication options. The graffiti and wall chalking on external surfaces offered an option for expression.

This study was done to examine the various formats of wall chalking observed in the city. For this purpose, six locations were chosen (see Figure 01). The objective of this documentation was to question the paradox of legal prohibition versus continued existence of wall chalking and the reasons behind its continued practice. The various formats of wall chalking are documented and analysed, and the social, cultural and political reasons and impacts are studied. The practice of wall chalking, as an informal practice is analysed, and theorized in relation to 'formal' ways of doing things. Six districts were chosen within Karachi. In East district, the precinct of mausoleum of Mohammad Ali Jinnah father of the nation was chosen. This location has been a regular recipient of wall chalking and graffiti input due to its physical profile, convergence of several streets, staging of rallies and processions as well as high daily commuting frequencies. In other words, a sizable number of citizens and visitors pass through any one of the corridors linked up with this site. Many prominent educational institutions are also situated along the location, walls of which are routinely used for chalking. Besides the intensity and connectivity of streets make this quadrangle a sought after context for promoters of wall chalking and graffiti.

In district west, Orangi town was focused being one of the largest squatter settlements with rapid morphological transformation, volatile political and cultural environment and multi-cultural social composition. It had one of the highest rates of wall chalking that appeared from time to time. Shah Faisal Colony was chosen in Korangi district as a low to middle income neighbourhood and active display of wall chalking of various orientations. Saddar, the city centre, was studied in district south, while Malir Colony was explored in district Malir. Each of these locations had a high concentration of wall chalking and graffiti in the respective case study areas (Table 1).

\section{Wall Chalking in Karachi: Findings}

A gist of interviews of political workers and covert religious groups is presented in this section. Table 2 informs about the typology of wall chalking and graffiti. As narrated, walls serve as urban notice boards due to many reasons. As mentioned different forms of wall chalking has deep rooted connection with specific culture (Mahmood, Saleem and Baig 2005) and ties up with the concept of broken windows (William and Kelling 1982). For many decades, the public walls in Karachi have continued to depict the political messages and slogans. Since the late 1970s, the political activities in the country in general and Karachi in particular were banned. Newspapers, magazines, telecast and broadcast media was under strict censorship due to military rule. For reaching out to masses and extending political messages to various communities across the city, wall chalking and graffiti were used to act as a populist medium. Despite the checks and controls on expression and political activities, wall chalking somehow remained largely unnoticed by the governing establishment of the time. Some outstanding impacts of wall chalking were support to the pro-democracy movement in 1980s that was covertly launched. The populist communication helped mobilise masses and organize struggle for the revival of democracy. The walls of Karachi and beyond carried the important instructions and messages for the masses in order to seek participation and 
keep them informed in pre-digital age. In other words, the walls served as the community bulletin boards displaying the trends of covert political activities across the metropolis. Spot responses to major political happenings and situations were also communicated through the walls of Karachi. Appeals to exonerate a former prime minister (before he was executed by the military regime in 1979); mass messages in support of jailed nationalist leaders; expression of solidarity with imprisoned Marxist leaders; messages welcoming the arrival of exiled leaders (in mid-1980's); support to US led Afghan Jihad (against former Soviet Union); fluctuating moods of religious parties; hailing the rise of local parties; fury at the arrest of various leaders and venom against periodic military take overs were subjects that covered wall surfaces in Karachi at a regular frequency. These aspects tie up to the notions of governance and the way informal processes are viewed or subscribed to within the formal spaces, as pointed out by Cathecart-Keays, 2015. The question about who owns the public space, how much control should be practiced therein, and what all can it communicate are some essentials questions that are gnerated with respect to governance (McAuliffe \& Iveson, 2011).

In the recent times, the wall chalking enterprise has become more vocal and visible. Workers and activists of political parties view wall chalking very favourably. According to the workers interviewed, the political wall chalking is done to achieve the party objectives especially during on-going election campaign (as observed in 2018 general elections). Top leadership decides about the slogans for communication during a call for strike or agitation. It is considered as an effective tool for mass communication. Political leadership favours wall chalking as it addresses almost all issues of importance through sharp phrases and messages. Concerns over the political impediments to judicial interventions for restoring human rights of minority communities; hate messages for threatening minority community members on issues such as blasphemy; support messages to local political parties; invitation to join protest rallies against rising influence of foreign powers in national / local matters; appreciation and laudatory remarks for the Pakistan Tehreek-e-Insaaf (Pakistan Movement for Justice) -the party that has formed the present federal government, threats and counter threats by political factions to each other constitute the usual array of substance projected through wall chalking (refer Tables $3 a$ and $3 b$ ).

Workers and activists of political parties view wall chalking very favourably. According to the workers interviewed, the political wall chalking is done to achieve the party objectives especially during on-going election campaign (as observed in 2018 general elections). Top leadership decides about the slogans for communication during a call for strike or agitation. It is considered as an effective tool for mass communication. Examples of messages are documented in Table 3s under the 'political' category, in the different case study areas. Political workers are given proper training in this trade. By continuing the practice, many workers become very skilful. They act as trainers and supervisors for the junior recruits. In a situation where larger areas have to be covered in a short time, the services of professional wall painters are also acquired. Tone and content is usually determined by the local office bearers of the party after consultation with the top leadership. Use of spray paints, stencils, oil paints, pointed brushes and pasting of posters are few common modes of using the walls. In usual circumstances, police does not object to wall chalking. It was reported by the political activist that they would bribe the local policemen for wall chalking. In return the police would allow it. In politically tense situation, approach and attitude of the police would change. When Section 144 of Penal Code is enforced, which prevents political activities and assembly of people, then quick service modes are used. Few slogans are used repetitively during agitation or call for rallies while for other purposes, the combination of slogans is applied. In Karachi, each unit of the political party is given its target of wall chalking during any forthcoming campaign. Along with wall chalking, pamphlets and banners are also used. Most political workers do this work free of charge for supporting the cause of the party. The fear of attacks from the rival factions of opponents also looms large. For instance, during the times when the rival groups of MQM (a local political party) were at logger heads with one another, each used to embark on wall chalking in the areas under the influence of the other. Police would round up the activists of both the groups and put them behind the bars for some time. After settling 
the matter with the police, the workers were released. In some cases, a First Information Report (FIR) was registered with the police after which the matter used to become serious.

Impacts of wall inscriptions are significant. A comparative advantage of wall chalking on other forms of publicity is that it stays intact for longer duration of time. Banners, pamphlets and posters wither away after a few days. Chalking stays till such time when the property owners paint the wall or a rival party replaces the slogans. The messages keep afresh in the memory of people, adding to the popularity of the concerned party, as found in Figure 09.

Summary of the interviews of graffiti artists and helping staff is stated here. According to them, the wall surfaces are also used for outdoor advertising by unbranded product manufacturers, informal traders and service providers of shady nature. Different types of traditional faith healers, herbal medicine experts and homeopaths put up serial messages on the walls, balustrades and other visible external surfaces. Keeping abreast with the modern day developments, they now offer packaged advices and products with some unqualified guarantees. Most of the advertisers only post cell numbers. In some cases, explicit references to countless alternative sources of medicine are rendered across the surfaces that do not escape the attention of passers-by and motorists. Laboratories, health centres, Acupuncture experts and hakims (traditional herbal medicine practitioners) are the fore runners in this health service drive (see commercial messages in case study areas Table 3a). By attracting a sizable clientele through such messages and campaigning, it is learned that few of these unscrupulous entrepreneurs have become wealthy. Stressed, dejected, frustrated, depressed and deprived common folks are forced to take notice of luring invitations by this category of service providers. Wall advertisements related to such outlets and trades are concentrated in the corridors of city centre, market places, traffic intersections, bus terminals and vicinity of congregation grounds. The wall chalking of all kind is done after mid night as the police and other government officials do not allow this work to be done. Even during the night, chalking operators keep a watch on the patrolling police vans and attempt to dodge them. The payment for the service is only done when the enterprises are satisfied that work has been done according to specifications. In cases when the police arrest the artists or their helping staff, they are made to seek legal help on their own. No assistance is given by those who hire their services. The work has to be done very quickly due to fear of arrests. Often the administration effaces the chalking from the walls. In this case, the work has to be done again. Political graffiti is done by the workers and sympathisers of respective parties. The artists are often called to paint specific messages and images on designated walls with proper themes. Such opportunities are very rare (see Figures 2-9)

Tables $3 \mathrm{a}$ and $3 \mathrm{~b}$ illustrates the documented contents in the six case locations including Quaid-e-Azam Mausoleum precinct, Orangi town, Shah Faisal Colony, Malir Colony, Saddar and Liaquatabad.

\section{Discussion: Typology of Graffiti on the Basis of Usage in Karachi}

Documentation and analysis of the various types of graffiti across the city revealed that the messages can be slotted into six typologies; commercial messages, political content, cultural and religious messages, hate messages, random messages and graffiti as a medium of art (Table 2). Thus, this discussion is divided accordingly. Tables $3 \mathrm{a}$ and $3 \mathrm{~b}$ further present the documented wall chalking messages according to the six locations.

\section{a. Commercial messages}

For promoting commercial enterprises and services found advertised through the walls, wall chalking is a much desirable option. Many of these services, such as faith healers, are legally and administratively prohibited to operate due to their dubious and unrecognized credentials. Besides witch craft, which these folks are found to perform, is a punishable crime. The clientele of such service providers come from people who are not familiar with digital advertising or do not possess the access to these sources. It is also interesting to find that ads of only those products and services are found on walls which are not accepted by the formal print or electronic media. Thus, the walls become the sole source for linking up through a cell phone contact. Similarly, the self-styled providers of medical services for various diseases, notably sexual disorders in men and women, use the walls to connect to 
their clientele. As the clinics that claim to offer treatments to such problems operate in a confidential manner, they succeed to attract respective clients. Evidences found in the Quaid-e-Azam's mausoleum precinct and Saddar area are prominent as these two locations are frequented by a sizable population belonging to the cross section of society interested in such solutions. The wall ads are painted along the main roads and streets where public transport routes are abundant and where large segments of working class move on a regular basis.

\section{b. Political Content}

The use of wall chalking and graffiti for political and protest related purposes is one of the most dominant options. It is this type which is found all across the city, including the six case locations with reasonable presence all the year round. Many purposes are served by wall chalking in this respect. In situations of political repressions against specific political parties, wall chalking becomes an active medium for communication. At present, a faction of Muttahida Qaumi Movement - the political party which used to be very dominant in Karachi's politics - is prohibited to carry out political activities. Thus, wall chalking for and against this party are visible, especially in Shah Faisal Colony, Orangi Town and Liaquatabad. Usually the wall chalking is done to inform people about party activities, hate promotion against a specific faction or leaders and recognizing the leaders of parties. In practice of power politics, slogans are posted on the walls to mark the territory of influence in certain neighbourhoods. Locations away from city centre display such messages in greater intensity. Active political debates and conflicts are often discussed in wall chalking conversations. Policy matters such as demands for creating a new province in southern Sindh - with Karachi as its centre - are also actively voiced through the walls.

\section{c. Cultural and Religious Messages}

The study area shows distinct moods of the promoters and practitioners of wall chalking and graffiti. Religious festivals and sombre occasions of both Shiite and Sunni Muslims are amply reflected along the walls. Mourning processions of Muharram (first lunar month of Islamic calendar) is welcomed with messages of religious nature. In this time period, the service providers of various kinds also tag messages of various essential services such as transport shuttles, supply of ritual accessories and sacred food. Announcement of timings of holy gatherings is also vehicled upon the walls of surrounding buildings. In many cases, printed posters are pasted on walls surfaces in high and repetitive frequencies. Barelvi sect of Sunni Muslims celebrates the birthday of the Holy Prophet Mohammad (May peace be upon him) around the same precinct. The walls of the same buildings are ornamented with welcome messages for the processions, sacred inscriptions and posters of various kinds. Informative messages for different groups of visitors about the dates and timings are also inscribed around the walls. The same precinct is swarmed with messages and inscriptions related to political rallies, marching orders to political activists by respective leaders and provocations leading to agitation and protests. Event based and reactionary responses to regional and global happenings are also manifested on the walls.

\section{d. Hate Messages}

Hate messages for American imperialism, anger against release of Aasia Bibi - the lady accused of blasphemy and acquitted by the Supreme Court, scathing criticism on the regime for its pro-western policies, rejection of price hikes of retail petroleum products and ordinary commodities and pressure signals to let free imprisoned political workers are the usual type of inscriptions found on the walls.

\section{e. Random Messages}

Many random messages can be seen across the public walls, reflecting a particular social and cultural setup of the city. These random messages range from welfare messages, to private announcements, to nationalistic messages like 'salute of our police martyrs'. Many of these messages also advertise emergency numbers to call an ambulance from different welfare organisations. This typology of wall chalking shows the reliance of formal sectors (For instance the Police Department and different welfare organisations) on this informal means of dissemination of information and promotion. 


\section{f. Graffiti as a Medium of Art}

Wall chalking and graffiti, as practiced in Karachi, stands very low on the scales of artistic acumen in the overall respect. There are several reasons behind this situation. The activity is done after midnight in a surreptitious manner to hide from the eyes of law enforcing agencies. Wall chalking is legally prohibited therefore its practitioners normally perform it through a clandestine approach in a most hurried fashion. As learned from the interviews of the wall chalking artists, they are either self-trained or receive some rudimentary tips from other practitioners in the field. They learn on the job around practical assignments. However, this trial and error method does not generate any higher quality output. The clients subscribing to wall chalking and graffiti are interested is most prominent and overpowering appearance of slogans or messages. Thus, the practitioners resort to black colour inscriptions and very large font sizes with almost no sense of composition. As figurative art is religiously denounced, therefore the chalking and graffiti is normally reduced to text messages only. The few walls where commissioned art work of some quality is done under permission are the sole exceptions. As a consequence of wall chalking and graffiti, there is a severe loss of aesthetical quality of the wall surface and the overall environment itself.

\section{Formality vs. Informality: Legal Status of Graffiti in Karachi}

Wall chalking and graffiti is described as a criminal activity. In Karachi, the Prevention of Defacement of Property Act 2014 regulates the wall chalking activity (GoS, 2014). With the exception of art work sanctioned and approved for designated boundary walls of public properties, the other types of wall chalking can lead to prosecution. Contents of the wall chalking can also cause legal action if any anti-state or objectionable post is found on the walls. However, very seldom are those legal clauses invoked as it is very difficult to apprehend those who conduct it. Besides the political parties, especially those in power, manage to protect their supporters and activists from possible prosecution. In addition, the administrative machinery is not able to control the rising tide of wall chalking. There are no designated spaces for free speech and expression in the city, though the Karachi
Press Club and its surroundings act as a defacto equivalent. The administration generally believes that ignoring wall chalking is perhaps a better policy and approach to make the masses vent out their frustrations, anger and contempt. Attempts to curb such moves - it is generally assumed by the various interviewed political stakeholders - can lead to greater urban unrest which may be difficult to manage and control. Only in situations of high political or religious tensions or when abusive language is used, the administrative units of the municipality wipe out the wall chalking by getting them painted white. Sometime later, the same walls become an ideal surface to post new messages!

As graffiti and wall chalking is supposed to be a reflection of the local culture (Mahmood, Saleem, \& Baig, 2005), it should be valued as such. Taking on from the concept of 'broken windows'Invalid source specified., it should be used to give cues to local agitations and believes. Within the informal paradigm wall chalking and graffiti should be viewed as a process which does tie up with the contestation of public spaces (Visconti, et al. 2010, $\mathrm{x}$ ) but is also a means to understand the local community which can in turn be used to design and develop spaces which are inclusive rather than exclusive. The messages communicated through these public walls should be as alternative and passive means of communication, rather than being viewed as an offense and criminal activity. As there is limited literature, documentation and scholarship on this means of communication in the global south, therefore this paper is meant to be a valuable addition towards this end.

\section{Conclusions and Way Forward}

The manner and process through which wall chalking is conducted on the city walls cause an intrusion, material harm and visual damage to the respective property owners. It is also evident that despite the regulatory checks and controls by city administration, the process continues on, almost unabated. The contents, especially the hate messages, can contribute to causing disharmony and unrest in the respective neighbourhoods. Threatening messages are also completely undesirable and require greater vigilance. The legal and statutory structure can be re-vamped through a consultative process. This may include the political parties at the starting stage and 
gradually expanding to other stakeholders. Wall chalking, an informal process, is used to disseminate information related to formal practices also, and its role in doing so is questionable.

To ensure a certain standard of messages put across the city walls, a consensus code of conduct may be developed by all the political parties to limit this activity through municipal permission. A comprehensive survey must be carried out to identify the congregation locations where graffiti may be allowed to take place. An effective facilitation mechanism is needed to take place without infringing on the rights of property owners.
Commercial messages may be charged according to a schedule of rates to make the property benefit from its wall usage pattern. The informal street artists, who develop their skills on a self-taught manner may be trained to undertake their work efficiently. And three, strict control must be exercised to curb the graffiti that is ill purposed. No message of a dubious faith healer or quack must be allowed to appear on the city walls. Lastly, the walls should not be left unpainted or they should have unfinished and coarse surface, to act as a deterrent for the wall chalking artist. If the walls of the city are properly kept, the scale of urban aesthetics can rise exponentially with very little input.

\section{References}

Bacharach, S. (2015, October). Street Art and Consent. British Journal of Aesthetics, 55(4), 481495.

Castellón, R. (1978). Aesthetics of Graffiti. San Francisco: Library of Congress.

Cathecart-Keays, A. (2015, January 7). Is urban graffiti a force for good or evil? . Retrieved September 8, 2018, from The Guardian:

https://www.theguardian.com/cities/2015/jan/07/urban-graffiti-force-good-evil

Chmielewska, E. (2005, November). Logos or the Resonance of Branding: A Close Reading of Ionosphere of Warsaw. Space and Culture, 8(4), 349-380.

City of Sydney. (2018). Graffiti Management Policy. City of Sydney: Mimeo.

Cohan, T. e. (1975). Street Writers: A Guided Tour of Chicano Graffiti. Los Anegles: Acrobat Books.

Dahdal, S. (2017). The Rhetoric of Political Graffiti on a Divisive Wall . Unpublished Doctoral Thesis. Arizona: Arizona State University, Tempe.

Dovey, K. (2012). Informal urbanism and complex adaptive assemblage. International Development Planning Review, 34(4), 349-367.

Freeman, S. A. (1966, October). Introduction. The Modern Language Journal, 50(6), 325-327.

Georgion, M. (2009). LSF research online. Retrieved 9 20, 2018, from Urban Encounters: Juxtapositions of Difference and the Communication Interface of Global Cities: http://eprints.lse.ac.uk/25637/

Gilmore, D. (2012). Another Brick in the Wall: Public Space, Visual Hegemonic Resistance, and the Physical/Digital Continuum. Thesis, Georgia State University.

Government of Sindh. (2014). Prevention of Defacement of Property Art. Karachi: Government of Sindh.

Hansen, T., \& Verkaaik, O. (2009). Introduction - Urban Charisma: On everyday Mythologies in the City. Critique of Anthopology 29 (Issue 1), 5-26. 
Klein, N. (2000). No Logo No Space, No Choice, No Jobs. New York: Picador.

Le Vine, M. (2015). When Art is the Weapon: Culture and Resistance Confronting Violence in Post Uprisings Arab World. Religions, 6, 1277-1313.

Lou, J. (2007, May). Revitalising China Town into a Heterotopia - A Geosemiotic Analysis of Shop Signs in Washington DC's China Town. Space and Culture,, 10(2), 170-194.

Mahmood, R., Saleem, F., \& Baig, F. Z. (2005). Stigmatized Public Literacies an Ethnographic Study of Ads of Local Films, Graffiti and \& Internet Chatting. American Journal of Scientific Research(98), 68-81.

McAuliffe, C., \& Iveson, K. (2011). Art and Crime (and Other Things Besides ... ): Conceptualising Graffiti in the City. Geography Compass, 2(3), 128-143.

Menor, L. (2015). Graffiti, Street Art and Culture in the era of Global City: The Ana Botella Crew Case. Street Art and Creativity Scientific Journal: Places and Non Places, 1(2), 59-71.

Obiozer, W. E. (2008). Language and Graffiti of Exceptional Individuals: Pedagogical strategies in West Africa. African Journal of Criminology \& Justice Studies, 3(32), 1-34.

Palmer, L. M. (2017). Rhizomatic Writings on the Wall: Graffiti and Street Art in Cochabamba, Bolivia, as Nomadic Visual Politics. International Journal of Communication, 11, 36553684 .

Seloni, L., \& Sarfati, Y. (2017). Linguistic Landscape of Gezi Park Protests in Turkey: A discourse analysis of Graffiti. Journal of Language and Politics, 16(6), 782-808.

Simone, A. M., \& Piererse, E. (2017). New Urban Worlds: Inhabiting Dissonant Times. Cambridge: Polity Books.

Srivathsan, A., Samuel, M., Pandian, S., \& Radhakrishnan, M. (2010). City in/as Graffiti: Chenani's many cities. Inter Asia Cultural Studies, 6(3), 422-427.

Visconti, L. M., Jr., J. F., Borghini, S., \& Anderson, L. (2010). Street Art, Sweet Art? Reclaiming the Public in Public Place. Journal of Consumer Research, 37, 000-000.

Wekker, F. (2017). Top down Community Building and the Politics of Inclusion. Amsterdam: Palgrave Macmillan.

William, J. Q., \& Kelling, G. L. (1982, March 10). Broken Windows: The Police and Neighbourhood Safety. The Atlantic.

World Bank. (2018). Karachi City Diagnostic. Washington D. C.: The World Bank.

Zukin, S. (1998). Urban Lifestyles: Diversity and Standardisation in Spaces of Consumption. Urban Studies, 35(5-6), 825-839. 


\section{Table 1: Table 1. Brief on Case Locations within Karachi}

\begin{tabular}{|c|c|}
\hline 1 & $\begin{array}{l}\text { The precinct around Quaid-e-Azam's Mausoleum (Quaid-e-Azam is the title given to the } \\
\text { founder of the nation and the first head of state Mohammed Ali Jinnah) is located on the prime } \\
\text { junction of major arteries of Karachi and form a focal point with respect to physical form. } \\
\text { The Mausoleum and its landscape serve as one of the few large open areas of the city, and is } \\
\text { an important landmark and point of orientation. Official and military ceremonies take place } \\
\text { here on special occasions, such as national commemoration days and birth and death } \\
\text { anniversaries of different head of states and certain national figures. Dignitaries and officials } \\
\text { from foreign countries also visit this place. Many people congregate in the premises on public } \\
\text { holidays. Political and religious rallies are also held in the vicinity including the Muharrem } \\
\text { (first month in Islamic calendar) procession for Shia Muslims and Rabi-ul-Awal (third month } \\
\text { in Islamic calendar) processions for Sunni Barelvi Muslims. Important city links such as } \\
\text { Preedy Street, Shahrah-e-Quaideen and M.A. Jinnah Road mark the location. As it is an } \\
\text { important landmark in the city and is frequented by people from different walks of life, all } \\
\text { types of graffiti and walk chalking can be seen here. }\end{array}$ \\
\hline 2 & $\begin{array}{l}\text { Saddar is the city centre of Karachi. It is located in Karachi south. It was an elite mixed use } \\
\text { location during the British colonial times. After independence, it has become the hub of retail, } \\
\text { transit and commercial activities for multiple social classes. Among other communities, } \\
\text { Christians, Parsis (Zoroastrians) and Shiite Bohra Muslims also reside in various sub locations } \\
\text { of Saddar. Over time Saddar has become a transit camp for public buses passing through the } \\
\text { locality, used by commuters travelling from the north to the south of the city. Besides many } \\
\text { administrative, institutional, religious and educations buildings are housed in the } \\
\text { neighborhood, so for people from all walks of life visit the neighborhood. Thus, the walls of } \\
\text { Saddar are important mediums to communicate messages to a wider audience. }\end{array}$ \\
\hline 3 & $\begin{array}{l}\text { Liaquatabad lies in Karachi Central. It evolved as a low to middle income residential } \\
\text { settlement. However, it has densities during the recent past and has experienced a land use } \\
\text { change from residential to mixed land use. Urdu speaking population is the major ethnic group } \\
\text { that resides in this area. It has been well known for intensive political activities. The } \\
\text { authorities had weak land control in Liaquatabad since its inception. Today the locality } \\
\text { requires new social and physical infrastructure development within to upgrade the entire } \\
\text { neighborhood. The previously orthogonal road structure was done away with and many cull } \\
\text { de sacs were created that limited exit points. As a result, this area became hide out for many } \\
\text { criminals. Liaquatabad today has a strong hold of the MQM and is a hot spot of the local } \\
\text { mafia. The political expression of the locality is evident in various categories of wall chalking } \\
\text { in the locality. }\end{array}$ \\
\hline 4 & $\begin{array}{l}\text { Orangi town is a large informal settlement in Karachi west. It originated as a combination of } \\
\text { a planned township of low income people which expanded through informal land sub } \\
\text { divisions of private and state land actors. In the early 1970s after the separation of the Eastern } \\
\text { Wing of Pakistan, thousands of migrants arrived and there was an acute shortage of housing. } \\
\text { Planned Orangi was still in the process of being inhabited. The existing road infrastructure of } \\
\text { the planned area was informally extended into vacant land around to form an informal } \\
\text { settlement. This was done by illegal sub-dividers. These extensions were on a regular grid } \\
\text { iron pattern. In relative terms, Orangi alone accommodated nearly } 30 \text { percent of the total } \\
\text { informal settlement population. Ethnic riots in the areas among the largely migrant population } \\
\text { led to most middle income families moving out. Plots of land were sold at cheap prices and } \\
\text { / or subdivided to be taken over by a largely lower income group. Today it possesses a } \\
\text { diverse population of various ethnicities and religion. Politically referring it has been a strong } \\
\text { hold of a political party Muthahida Qaumi Movement (MQM) (a political party of Urdu } \\
\text { speaking community who migrated from India in 1947) since 1980s. Due to continuing } \\
\text { migrations from the north of the country, the diversity in community has enhanced over the } \\
\text { period of time. It has suffered from politically, religious and ethnically motivated violence } \\
\text { from time to time which is also reflected through various wall chalking and hate speech } \\
\text { expressions in the locality. }\end{array}$ \\
\hline
\end{tabular}




\begin{tabular}{|c|c|}
\hline 5 & $\begin{array}{l}\text { Malir district used to be the suburb locality of Karachi, known for agricultural and pastoral } \\
\text { activities, because of the presence of the Malir River. It has experienced significant land } \\
\text { change in the recent past. Malir colony, within the district, is a typical low to lower middle } \\
\text { income settlement. It largely comprises of a working class population, from Urdu speaking } \\
\text { background. The other interest group, however, belongs to Baloch and Sindhi speaking } \\
\text { backgrounds and are engaged in agriculture, livestock farming and work as laborers. Since it } \\
\text { is largely a low income settlement where different economic frustrations are often expressed } \\
\text { in the form of wall chalking. }\end{array}$ \\
\hline 6 & $\begin{array}{l}\text { Shah Faisal Colony is a residential settlement in Korangi district. It is composed of Urdu } \\
\text { speaking community. The area has experienced bouts of violence followed by crack down by } \\
\text { security forces. Residential units are a mixture of old and new structures. Till date Shah Faisal } \\
\text { Colony remains sparsely populated and lacks good connections with the rest of the city. The } \\
\text { physical degradation results in frustration amongst the residents and is often expressed on the } \\
\text { walls of the locality. As the neighborhoods is not well connected with the rest of the city, it } \\
\text { also becomes a breeding ground for criminal activities and at times these people who transit } \\
\text { in the neighborhood use the walls to entice anti-government or sentiments against certain } \\
\text { political or secretarian groups. }\end{array}$ \\
\hline
\end{tabular}

Table 2: Typology of graffiti on the basis of usage in Karachi

\begin{tabular}{|c|c|c|}
\hline Purpose & Examples & Remarks \\
\hline Commercial & $\begin{array}{l}\text { Advertisement on wall about faith } \\
\text { healers, medicines, clinics for } \\
\text { sexually transmitted diseases; } \\
\text { match making enterprises }\end{array}$ & $\begin{array}{l}\text { - Low budget } \\
\text { - Promotes spurious and unbranded products and } \\
\text { services. } \\
\text { - Option of advertising for such services and } \\
\text { products which may not be accepted by formal } \\
\text { media }\end{array}$ \\
\hline $\begin{array}{l}\text { Protest and } \\
\text { political } \\
\text { content }\end{array}$ & $\begin{array}{l}\text { Inter party political messages call } \\
\text { for strikes, demand statements for } \\
\text { developments in certain areas }\end{array}$ & $\begin{array}{l}\text { - Display of political power } \\
\text { - Ease in posting dissent } \\
\text { - Settling political conflicts } \\
\text { - Reactionary slogans } \\
\text { - Advertising political rallies and procession. } \\
\text { - Praise and venom for leaders and parties. }\end{array}$ \\
\hline $\begin{array}{l}\text { Cultural and } \\
\text { religious } \\
\text { message }\end{array}$ & $\begin{array}{l}\text { Promotion of sect specific events } \\
\text { as per religious calendar; } \\
\text { announcements of events; critical } \\
\text { and reactionary statements; } \\
\text { provocation and anti-state claims }\end{array}$ & $\begin{array}{ll}\text { - } & \text { Extensive promotion of religious events } \\
\text { - } & \text { Marking territory of influence } \\
\text { - } & \text { Show of strength and power } \\
\text { - } & \text { Veiled threats to opponents } \\
\text { - } & \text { Reaction campaigns } \\
\text { - } & \text { Demands for conflict / issue resolution } \\
\end{array}$ \\
\hline $\begin{array}{l}\text { Hate } \\
\text { messages and } \\
\text { material }\end{array}$ & $\begin{array}{l}\text { Promoting power messages to } \\
\text { political or sectarian opponents }\end{array}$ & $\begin{array}{l}\text { - } \quad \text { Contents is both sectarian, political and ethnic; } \\
\text { direct and indirect messages } \\
\text { - } \quad \text { Extensive use of unparliamentarily language } \\
\text { - } \quad \text { Sudden overnight emergence }\end{array}$ \\
\hline $\begin{array}{l}\text { Random } \\
\text { messages }\end{array}$ & 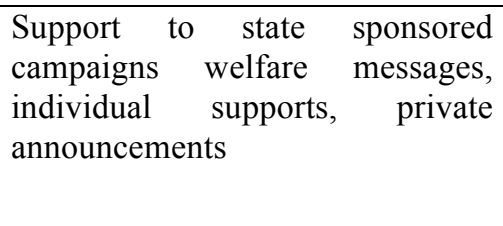 & $\begin{array}{l}\text { - One off exercises } \\
\text { - Campaign related } \\
\text { - Often functional and related to specific } \\
\text { institutions } \\
\text { - Benign in content }\end{array}$ \\
\hline $\begin{array}{l}\text { Medium for } \\
\text { art work }\end{array}$ & $\begin{array}{lrr}\begin{array}{l}\text { Attempts } \\
\text { authorities, }\end{array} & \begin{array}{r}\text { improve } \\
\text { celebrating city }\end{array} & \text { and } \\
\text { remembering } & \text { important } \\
\text { personalities } & & \end{array}$ & $\begin{array}{l}\text { - } \text { Efforts to reclaim verified spaces along the city } \\
\text { wall } \\
\text { - } \quad \text { Thematic in content } \\
\text { - High quality of skill and output }\end{array}$ \\
\hline
\end{tabular}

Source: Authors derivations from the photographic documentation, observation of case counters and response from interview of stakeholders during January to November 2018 
Table 3a: Selected contents of wall chalking and graffiti in Karachi

\begin{tabular}{|c|c|c|c|c|c|c|}
\hline & Quaid -e- Azam Mausoleum Precinct & Saddar & Liaquatabad & Orangi Town & Malir & Shah Faisal Colony \\
\hline$\sum_{0}^{\frac{1}{u}}$ & $\begin{array}{l}\text { - Perfume chowk } \\
\text { - Tara Masih } \rightarrow \text { You will get all your } \\
\text { - } \text { desires fulfilled (faith healer) } \\
\text { - Uride batteries } \\
\text { - Nelson Paints } \\
\text { - Goher Kalia (faith healer) } \\
\text { - Boota Masih (faith healer) } \\
\text { - Rustom Bengali (faith healer) } \\
\text { - Junaid Bengali (faith healer) } \\
\text { - Pir Dilawar Shah (spiritual guide) } \\
\text { - Shan Bengali (faith healer) Get your } \\
\text { favorite bride }\end{array}$ & $\begin{array}{l}\text { - Nelson } \\
\text { paints } \\
\text { - Nippon } \\
\text { paints } \\
\text { - Tibet } \\
\text { snow } \\
\text { - Perfume } \\
\text { chowk }\end{array}$ & $\begin{array}{l}\text { - Reliance paints } \\
\text { - Nelson paints } \\
\text { - Jawa paints } \\
\text { - Final touch paint } \\
\text { - Use our } \\
\text { medicines - } \\
\text { make your } \\
\text { bodies stronger } \\
\text { (phone given) }\end{array}$ & $\begin{array}{l}\text { - Junaid Bengali faith } \\
\text { healers } \\
\text { - Prakash Bengali faith } \\
\text { healers } \\
\text { - Try our medicine for } \\
\text { changing your body } \\
\text { measurements }\end{array}$ & $\begin{array}{l}\text { - Ahsan copy house and } \\
\text { stationary }\end{array}$ & $\begin{array}{l}\text { - Health supplement - } \\
\text { improve your health } \\
\text { - Perfume chowk } \\
\text { - Sayal clinic-improve your } \\
\text { height } \\
\text { - Al-Umer coaching Centre- } \\
\text { Classes for high school } \\
\text { - Little step Montessori } \\
\text { - Star Coaching Centre }\end{array}$ \\
\hline 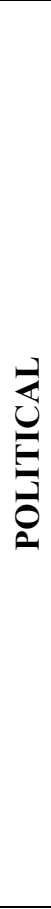 & $\begin{array}{l}\text { - 34th thanks giving day of MQM } \\
\text { (Muthahida Quami Movement) } \\
\text { - Karachi belongs to all } \\
\text { - Pakistan first (APML) } \\
\text { - Long live Afaq (MQM-H) } \\
\text { - Long Live PSP (PSP) } \\
\text { - Long Live Mustafa Kamal (PSP) } \\
\text { - Long Live Amir Liaqat (PTI) }\end{array}$ & $\begin{array}{l}\text { - Long } \\
\text { live } \\
\text { Kamal } \\
\text { (PSP) } \\
\text { - Long } \\
\text { live } \\
\text { Mustafa } \\
\text { Kamal }\end{array}$ & $\begin{array}{l}\text { - Long live } \\
\text { (General) } \\
\text { Musharraf } \\
\text { - We want a new } \\
\text { province in } \\
\text { south of Sindh } \\
\text { - South Sindh } \\
\text { province for } \\
\text { Mahajir } \\
\text { - Long live Afaq } \\
\text { - We reject the } \\
\text { resignation of } \\
\text { Afaq Bhai } \\
\text { (residents of } \\
\text { Karachi) } \\
\text { - Long live } \\
\text { Bilawal Bhutto } \\
\text { - Long Live Aman } \\
\text { (PPP) } \\
\text { - MQM Pakistan }\end{array}$ & $\begin{array}{l}\text { - Vote for Haji Jamal } \\
\text { Zia (NA-251) } \\
\text { - Vote for Shahida } \\
\text { Rahmani } \\
\text { - Vote for PSP / } \\
\text { Mustafa Kamal } \\
\text { - Long live Pakistan } \\
\text { - long live Anis Kaim } \\
\text { Khani (MQM) } \\
\text { - Long live Mustafa } \\
\text { Kamal (PSP) } \\
\text { - Altaf father of the } \\
\text { Mohajir nation } \\
\text { (MQM) }\end{array}$ & $\begin{array}{l}\text { - America is responsible for all } \\
\text { the troubles of Muslims } \\
\text { (Khomeini) } \\
\text { - Let us go to Liaqatabad (to } \\
\text { listen to MQM leaders) } \\
\text { - Long live peoples party and } \\
\text { its leader Jahan Zaib Khan } \\
\text { - Thanks giving day of APMSO } \\
\text { (All Pakistan Mohajir } \\
\text { Students Organization) } \\
\text { - Long live Altaf Hussain } \\
\text { - Long live (General) } \\
\text { Musharraf } \\
\text { - Remove restrictions from } \\
\text { MQM leaders (Altaf Hussain) } \\
\text { - Long live Pir Pagara } \\
\text { - Long live PSP and Mustafa } \\
\text { Kamal } \\
\text { - Long live MQM Pakistan and } \\
\text { its symbol (Kite) } \\
\text { - Long live Saleem Qadri } \\
\text { (Sunni Tehreek) }\end{array}$ & $\begin{array}{l}\text { - Mustafa Kamal must be } \\
\text { supported-support dolphin } \\
\text { - Sunni Tehreek and Sarwat } \\
\text { Qadri must be supported } \\
\text { - Bread, clothing and shelter, } \\
\text { Pakistan Peoples Party } \\
\text { - Long live Bilawal Bhutto } \\
\text { - Benazir - symbol of } \\
\text { federation } \\
\text { - Long live Mohajir- long } \\
\text { live Afaq (MQM) } \\
\text { - Long live Mohajir- long } \\
\text { live Altaf (MQM) } \\
\text { - Long live Anis Kaim Khani } \\
\text { (MQM) } \\
\text { - Pakistan Muslim League- } \\
\text { Functional } \\
\text { - Lets go to Liaqatabad (for } \\
\text { MQM rally) } \\
\text { - Anjuman -e- Tulba Islam } \\
\text { - We want Altaf only (MQM) }\end{array}$ \\
\hline
\end{tabular}




\begin{tabular}{|c|c|c|c|c|c|c|}
\hline & & & $\begin{array}{l}\text { - Election symbol } \\
\text { cricket bat for } \\
\text { PTI } \\
\text { - Saddenned } \\
\text { Muslim } \\
\text { association } \\
\text { (election symbol } \\
\text { bunch) }\end{array}$ & & $\begin{array}{l}\text { - Several thanksgiving day } \\
\text { (PSP) } \\
\text { - We will win on } 25 \text { July } 2018 \\
\text { (PSP) } \\
\text { - TLP (Tehreek e Labbaik) } \\
\text { - Fight for province South }\end{array}$ & $\begin{array}{l}\text { - Long live PTI and Imran } \\
\text { khan (PTI) } \\
\text { - Let us go to Al Hamza } \\
\text { ground (to listen to the } \\
\text { speech of Mr. Afaq Ahmed) } \\
\text { (MQM) }\end{array}$ \\
\hline 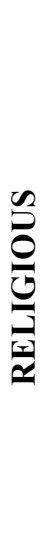 & $\begin{array}{l}\text { - Mere teachings do not make } \\
\text { Khomeini. It is the divine religion that } \\
\text { makes Khomeini } \\
\text { - God is our creator Holy Prophet } \\
\text { Muhammad (PBUH) is our leader } \\
\text { - Free Jerusalem } \\
\text { - Long live martyrs of Parachinar } \\
\text { - Down with the friends of Yazid } \\
\text { - Down with America! } \\
\text { - Holy Quran is our guide } \\
\text { - Jihad is our path } \\
\text { - Martyrdom is our derives } \\
\text { - Heaven is our destination }\end{array}$ & $\begin{array}{l}\text { - Long } \\
\text { live the } \\
\text { Holy } \\
\text { Prophet } \\
\text { (PBUH) } \\
\text { - Long } \\
\text { live } \\
\text { Tehreek- } \\
\text { e-Labaik } \\
\text { Pakistan }\end{array}$ & $\begin{array}{l}\text { - } \text { Prayers are a } \\
\text { pillar of } \\
\text { (Islamic) } \\
\text { religion }\end{array}$ & $\begin{array}{l}\text { - No compromise on } \\
\text { the finality of Holy } \\
\text { Prophet (PBUH) } \\
\text { - Long live Tehreek-e- } \\
\text { Labaik Pakistan } \\
\text { (religio-political party } \\
\text { of Barelvi Muslims) } \\
\text { - Long live Muthahida } \\
\text { Majlis-e-Amal } \\
\text { (religio-political party } \\
\text { of combining several } \\
\text { Muslim factions) }\end{array}$ & $\begin{array}{l}\text { - 'O' Allah } \\
\text { - 'O'Prophet (PBUH) } \\
\text { - Happy birthday of Holy } \\
\text { Prophet (PBUH) }\end{array}$ & $\begin{array}{l}\text { - Long live the Holy Prophet } \\
\text { (peace be upon him) } \\
\text { - We are coming to follow } \\
\text { your footsteps (Holy } \\
\text { Prophet (peace be upon } \\
\text { him)) } \\
\text { - Happy anniversary (Holy } \\
\text { Prophet (peace be upon } \\
\text { him)) } \\
\text { - Welcome (Holy Prophet } \\
\text { (peace be upon him)) }\end{array}$ \\
\hline
\end{tabular}

Table 3b: Selected contents of wall chalking and graffiti in Karachi (continued)

\begin{tabular}{|c|c|c|c|c|c|c|}
\hline & $\begin{array}{l}\text { Quaid -e- Azam Mausoleum } \\
\text { precinct }\end{array}$ & Saddar & Liaquatbad & Orangi Town & Malir & Shah Faisal Colony \\
\hline 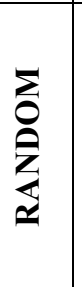 & $\begin{array}{l}\text { - Daily media post (newspaper) } \\
\text { - } 1091 \text { helpline for children } \\
\text { rights - contact for seeking } \\
\text { assistance in case of children } \\
\text { abuse and kidnappings }\end{array}$ & $\begin{array}{l}\text { - Call } 115 \text { for Edhi ambulance } \\
\text { - Call } 1020 \text { for Chippa ambulance } \\
1020 \\
\text { - Salute to our Police Martyrs }\end{array}$ & $\begin{array}{l}\text { - Keep Karachi clean } \\
\text { - Wall of kindness } \\
\text { (donate articles of } \\
\text { use that you do not } \\
\text { need) } \\
\text { - Help Sindh police in } \\
\text { monitoring }\end{array}$ & $\begin{array}{l}\text { - Nelsons paints } \\
\text { - For calling Edhi } \\
\text { ambulance please } \\
\text { dial } 115\end{array}$ & $\begin{array}{l}\text { - Long live } \\
\text { Inspector } \\
\text { General Police } \\
\text { - Youth } \\
\text { empowering } \\
\text { space (YES) }\end{array}$ & $\begin{array}{l}\text { - Let us go to attend } \\
\text { political rallies of } \\
\text { our favorite leaders }\end{array}$ \\
\hline 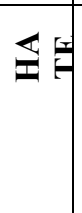 & $\begin{array}{l}\text { - Down with friends of Yazid } \\
\text { - Down with America! }\end{array}$ & $\begin{array}{l}\text { - Hate messages have been largely } \\
\text { removed }\end{array}$ & $\begin{array}{l}\text { Killer of Mohajir- } \\
\text { Altaf (Anti MQM) }\end{array}$ & $\begin{array}{l}\text { - } \text { Down with } \\
\text { Holland } \\
\text { - Hang Aasia } \\
\text { - Punishment for } \\
\text { disrespect is death }\end{array}$ & $\begin{array}{l}\text { America is } \\
\text { responsible for } \\
\text { all the troubles of } \\
\text { Muslims }\end{array}$ & $\begin{array}{l}\text { - Killer party PSP } \\
\text { - Killer Amir Khan (of } \\
\text { MQM) }\end{array}$ \\
\hline
\end{tabular}




\begin{tabular}{|c|c|c|c|c|c|c|}
\hline & & & & $\begin{array}{l}\text { - Disrespectful } \\
\text { Aasia should be } \\
\text { hanged } \\
\text { - Imran khan you } \\
\text { should be ashamed } \\
\text { of your life } \\
\text { - Hang Asia, } \\
\text { otherwise .....!!! } \\
\text { - Down with IMF } \\
\text { - Become a good } \\
\text { Muslims, } \\
\text { otherwise .... !!! } \\
\end{array}$ & $\begin{array}{l}\text { (Ayatullah } \\
\text { Khomeini) } \\
\text { - Karachi Electric } \\
\text { is a thief } \\
\text { (Electric Power } \\
\text { Company of the } \\
\text { city) } \\
\text { - Down with } \\
\text { Karachi Electric }\end{array}$ & $\begin{array}{l}\text { - Down with Rao } \\
\text { Anwar (Police } \\
\text { Officer) } \\
\text { - Zahid Hamid (is a } \\
\text { dog) (former Focal } \\
\text { Law minister) } \\
\text { - Nawaz Sharif (is a } \\
\text { day) (former Prime } \\
\text { Minister) } \\
\text { - Altaf is a killer } \\
\text { (MQM) } \\
\text { - Traitors, Beware, we } \\
\text { (Altaf) is back } \\
\text { - Let us boycott BOL } \\
\text { (TV Channel) } \\
\text { - Amir Liaquat (now } \\
\text { PTI leader) is a dog ! } \\
\text { - Peoples Party is a } \\
\text { killer of Mohajirs } \\
\text { - Hang (General) } \\
\text { Musharraf } \\
\text { - Down with (United } \\
\text { States of) America }\end{array}$ \\
\hline 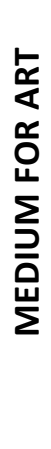 & $\begin{array}{l}\text { Under municipal } \\
\text { passages, may walls of } \\
\text { public buildings have } \\
\text { been allocated to art } \\
\text { group, mostly } \\
\text { belonging to youths } \\
\text { from art schools. They } \\
\text { have painted sceneries } \\
\text { from daily life in } \\
\text { Pakistan }\end{array}$ & $\begin{array}{l}\text { - Outstanding examples of } \\
\text { art work are found in } \\
\text { different locations in } \\
\text { Saddar; Bohra community } \\
\text { life style is painted near } \\
\text { St. Joseph college walls- it } \\
\text { illustrates comments } \\
\text { living patterns, ------- of } \\
\text { dining and places of } \\
\text { worship of Bohra } \\
\text { community }\end{array}$ & $\begin{array}{l}\text { Wall mural } \\
\text { painting } \\
\text { depicting trees } \\
\text { and } \\
\text { blossoming } \\
\text { flowers }\end{array}$ & $\begin{array}{l}\text { Evidence of art } \\
\text { work not found }\end{array}$ & $\begin{array}{l}\text { - Art work } \\
\text { depriving the } \\
\text { Holy Mosque in } \\
\text { Saudi Arabia }\end{array}$ & $\begin{array}{l}\text { - Stencil work of } \\
\text { national } \\
\text { - monuments printed } \\
\text { on the walls }\end{array}$ \\
\hline
\end{tabular}




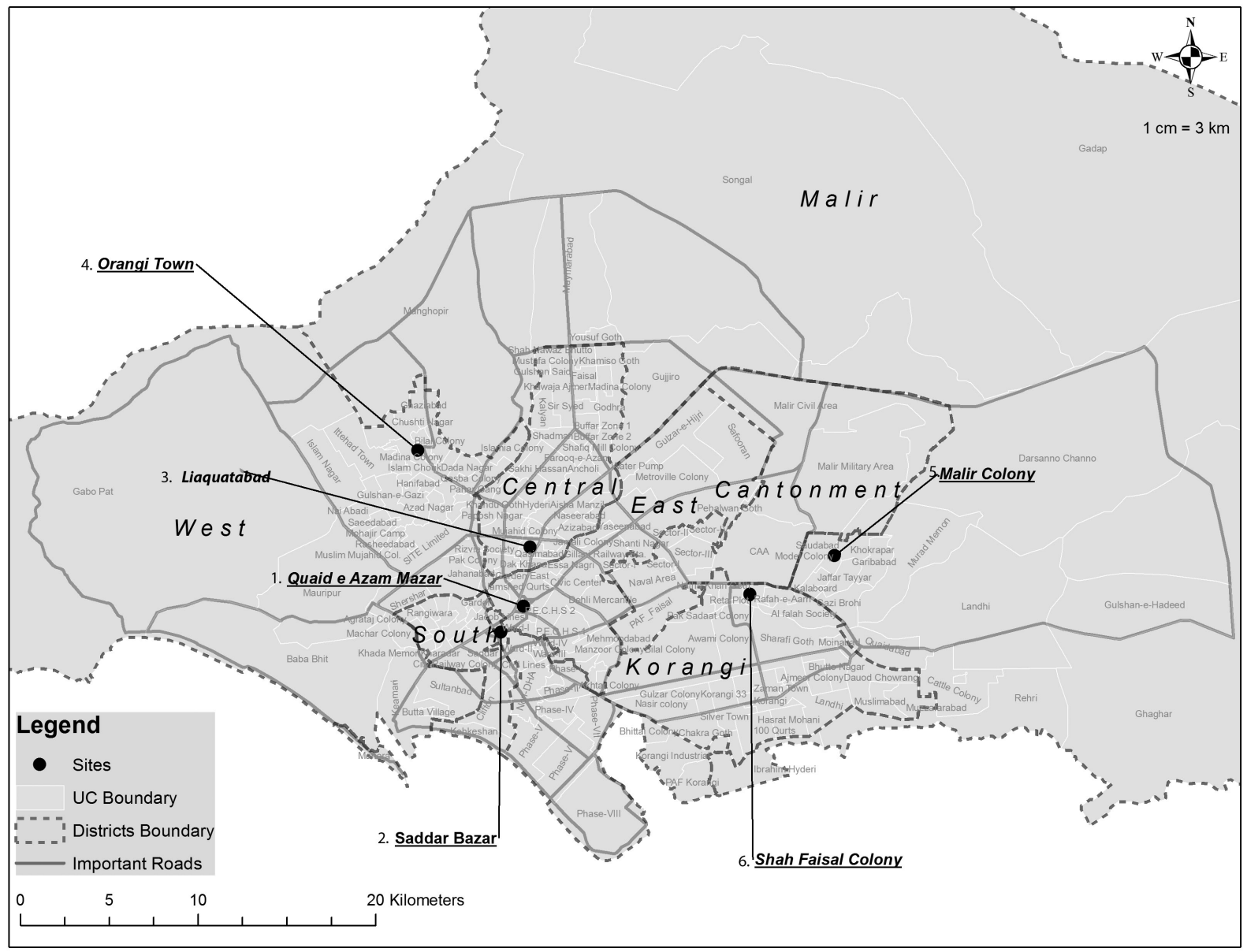

Figure 1. Locations of Case Study Work. 2018

Source: Authors

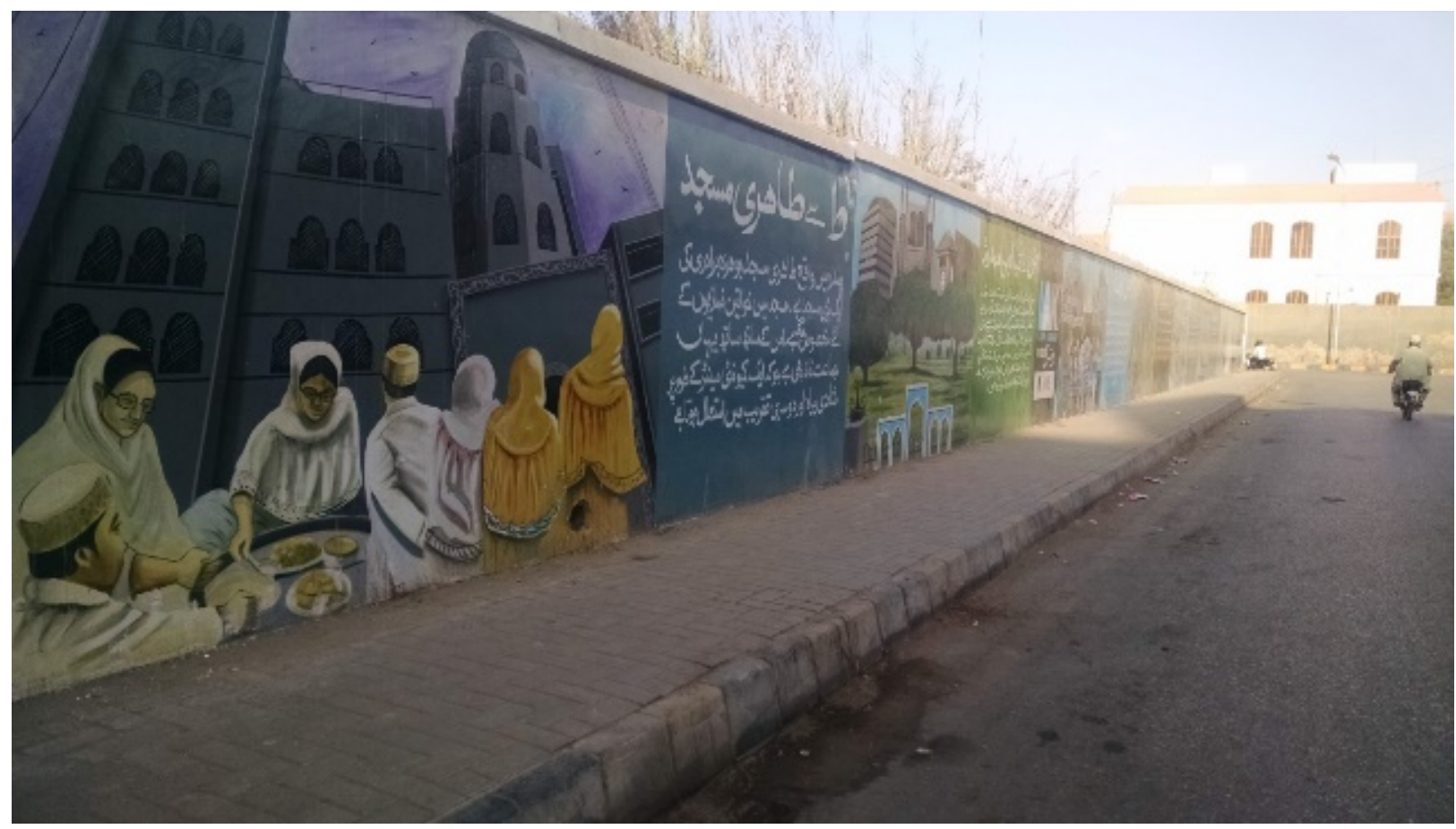

Figure 2: Art work depicting Bohra Community life style in Saddar. 2018 Source:Authors 


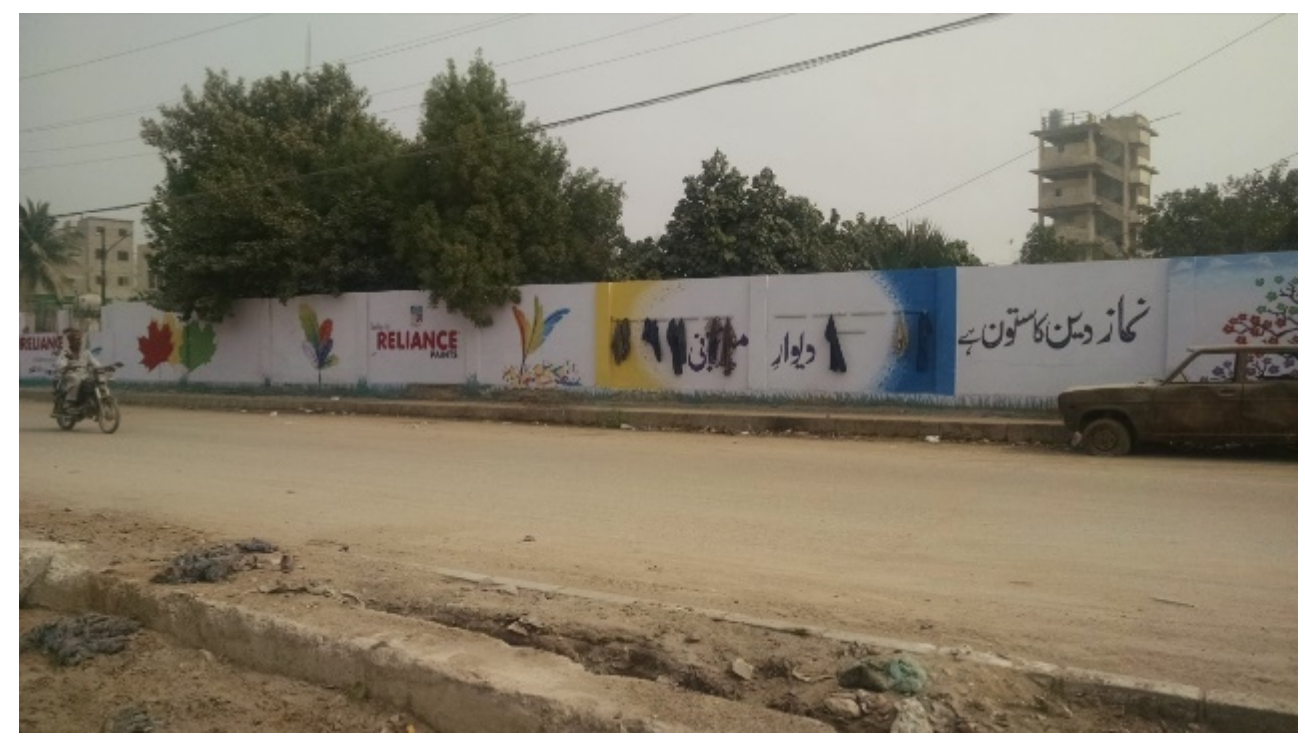

Figure 3: Walls in Liaquatabad used for commercial advertisement. 2018 Source: Authors

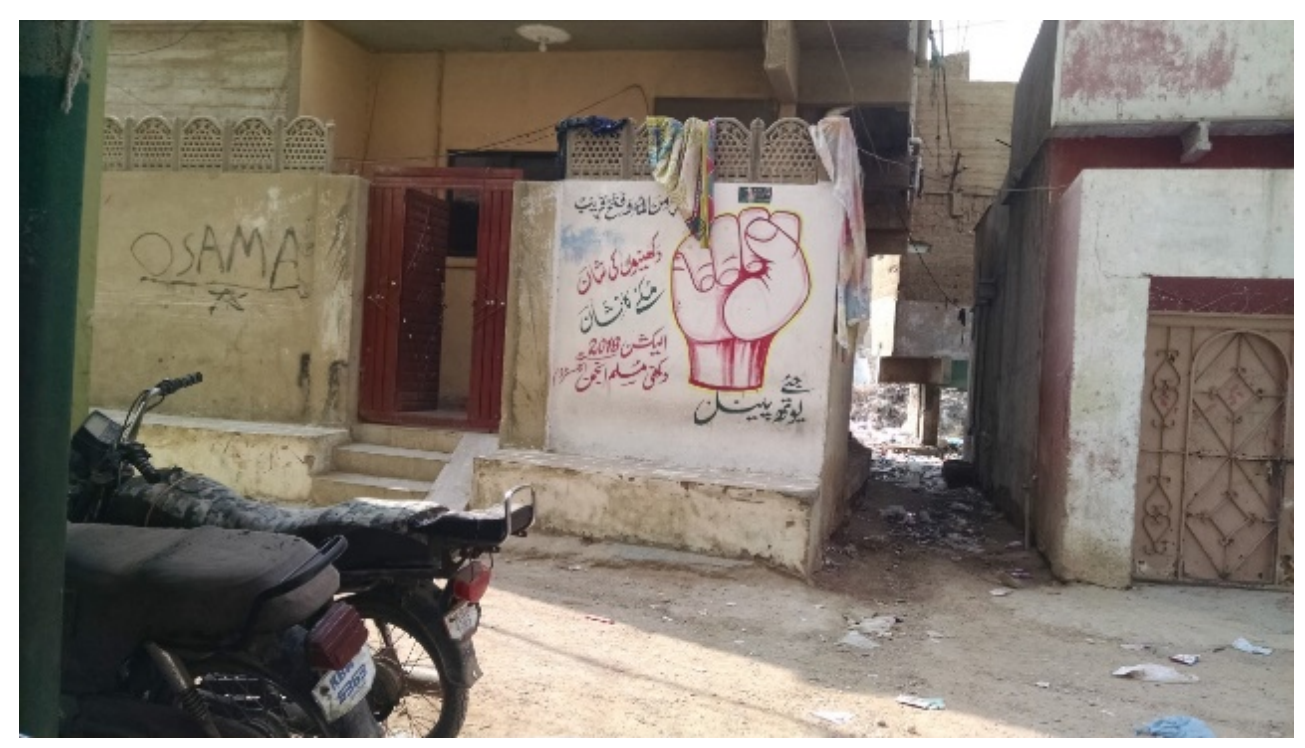

Figure 4: Wall in Liaquatabad showcasing the electoral symbol of MQM (the fist). Source: Authors

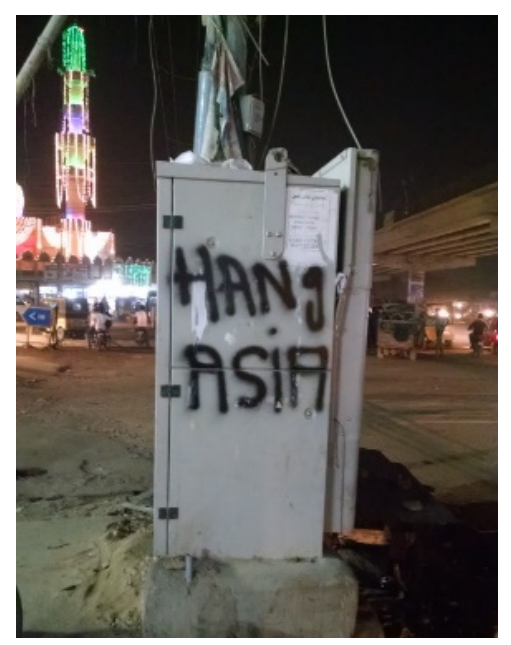

Figure 5: Examples of wall chalking depicting negative sentiments in Orangi.

Source: Authors 


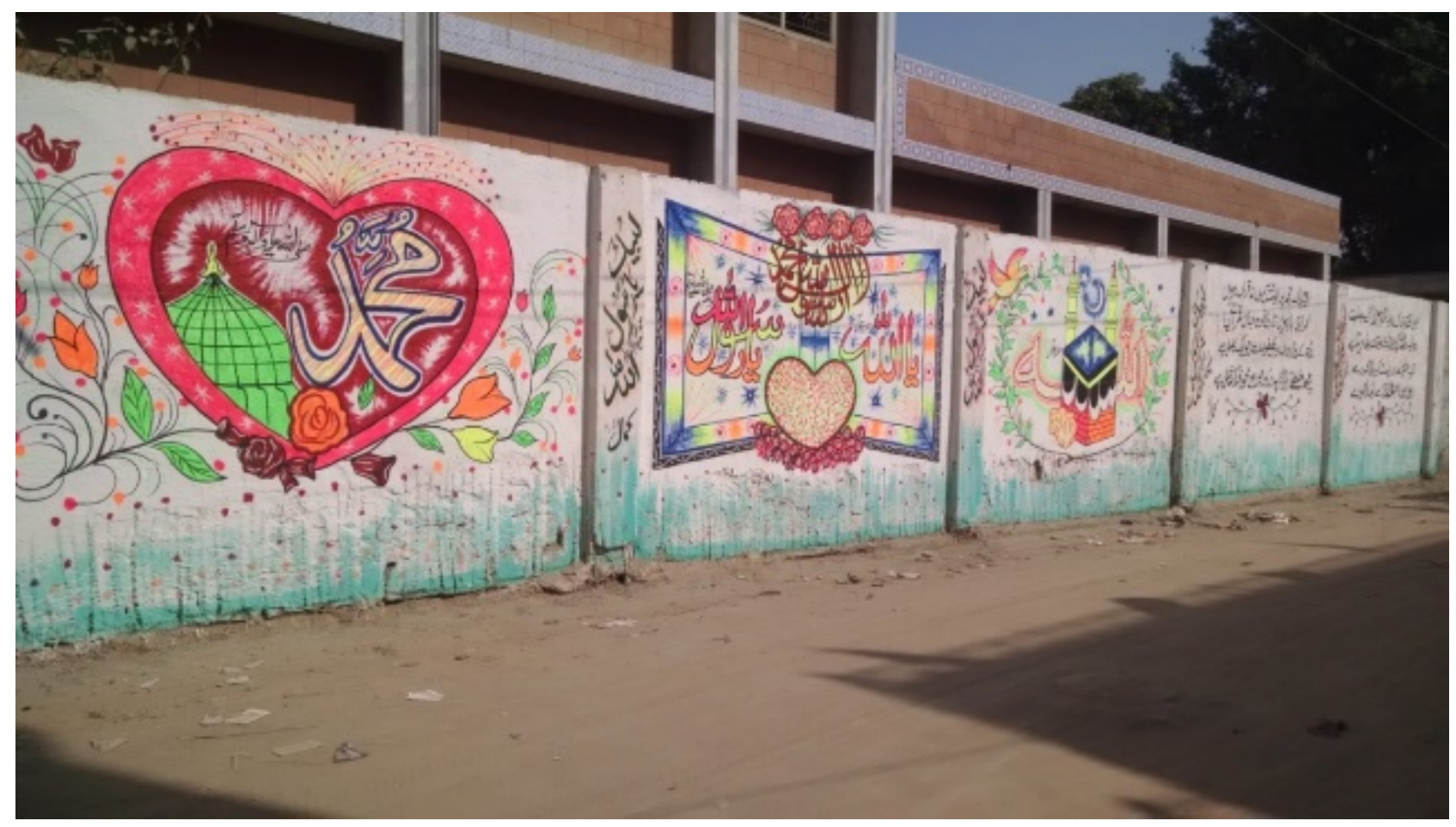

Figure 6: Walls in Malir on the occasion of birth of the Prophet (PBUH). Source: Authors

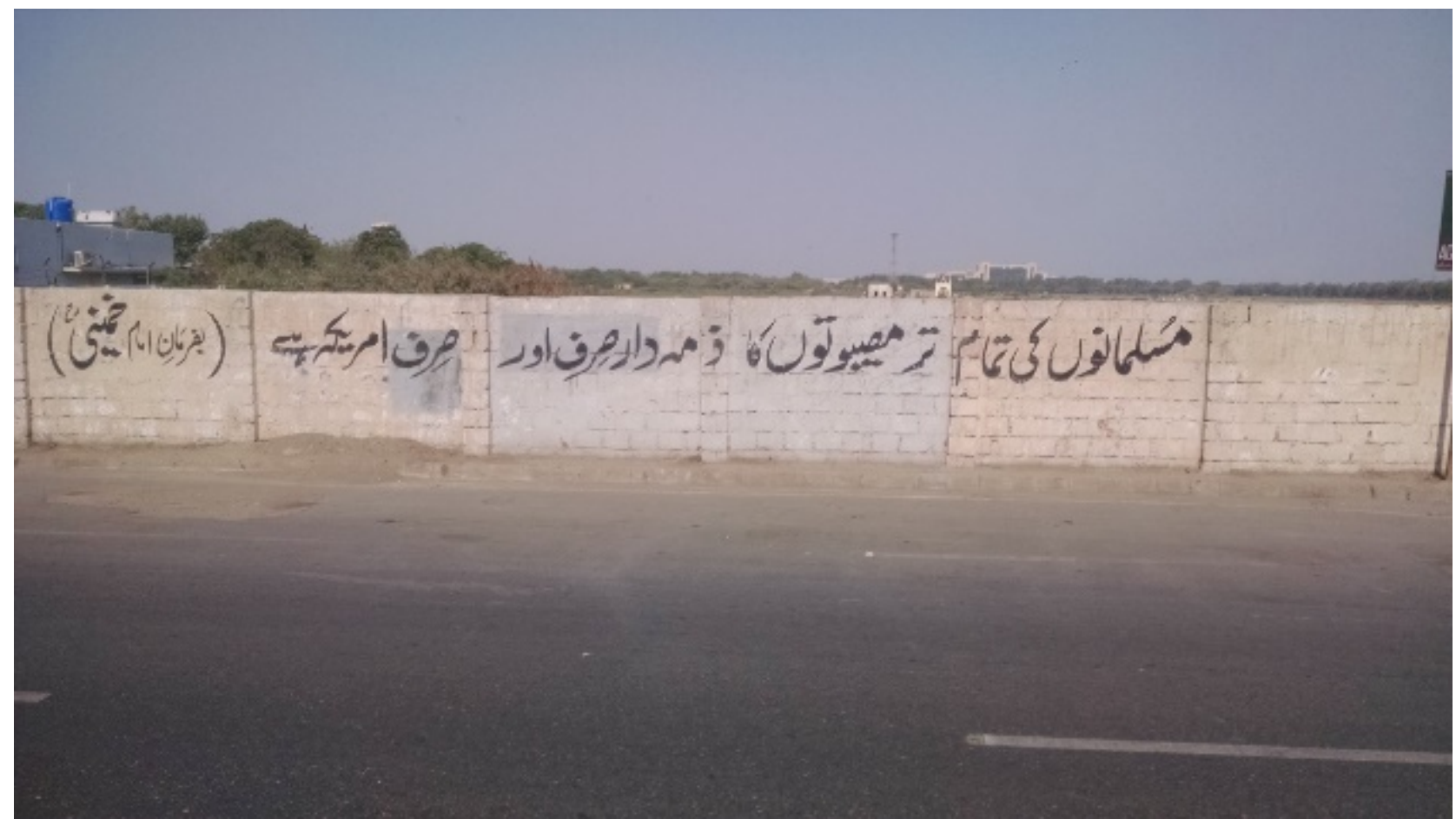

Figure 7:Walls in Malir blaming USA for all the problems of the Muslim community. Souce: Authors 


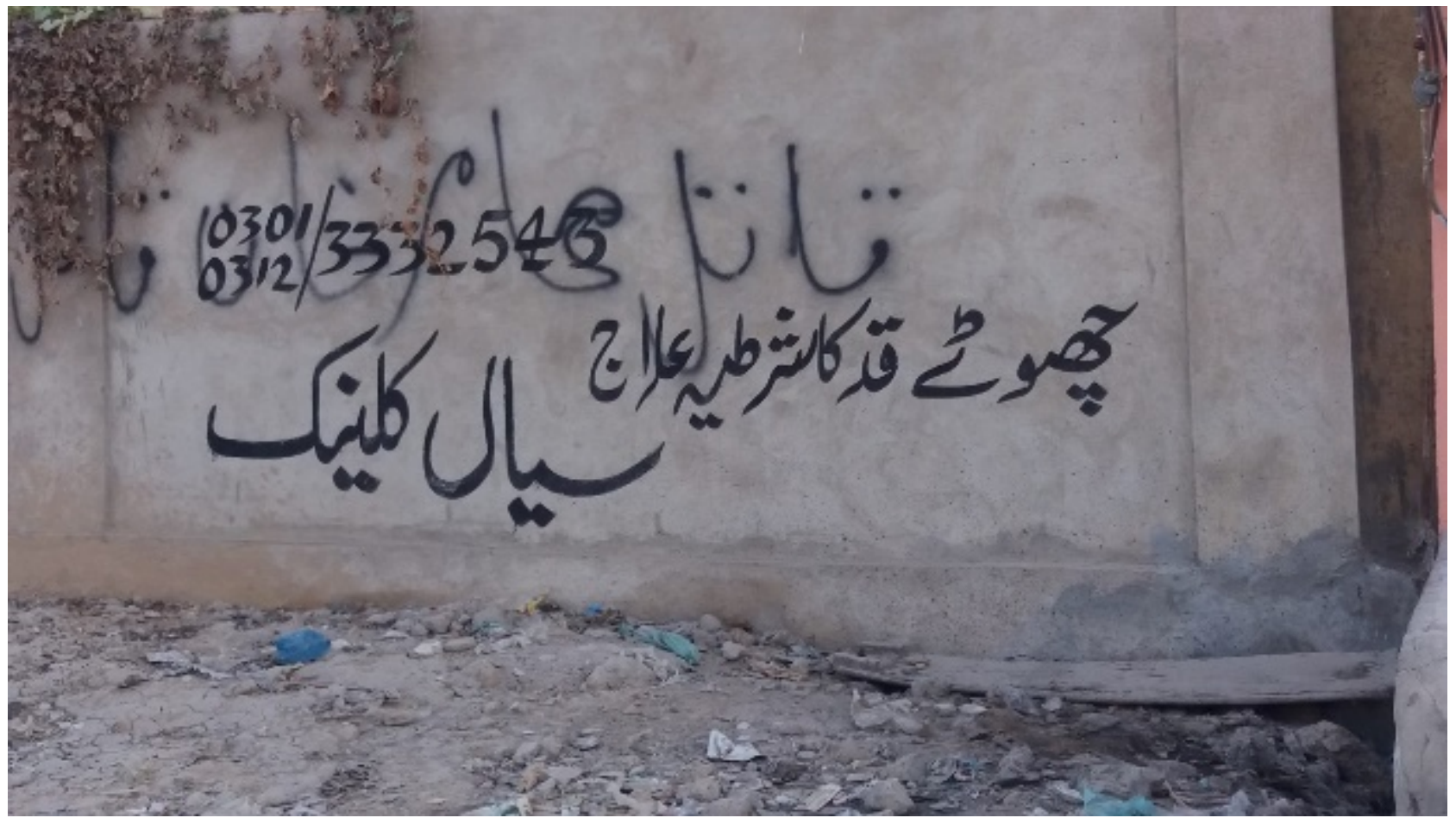

Figure 8: A wall in Shah Faisal Colony advertising the solution for short height.

Source: Authors

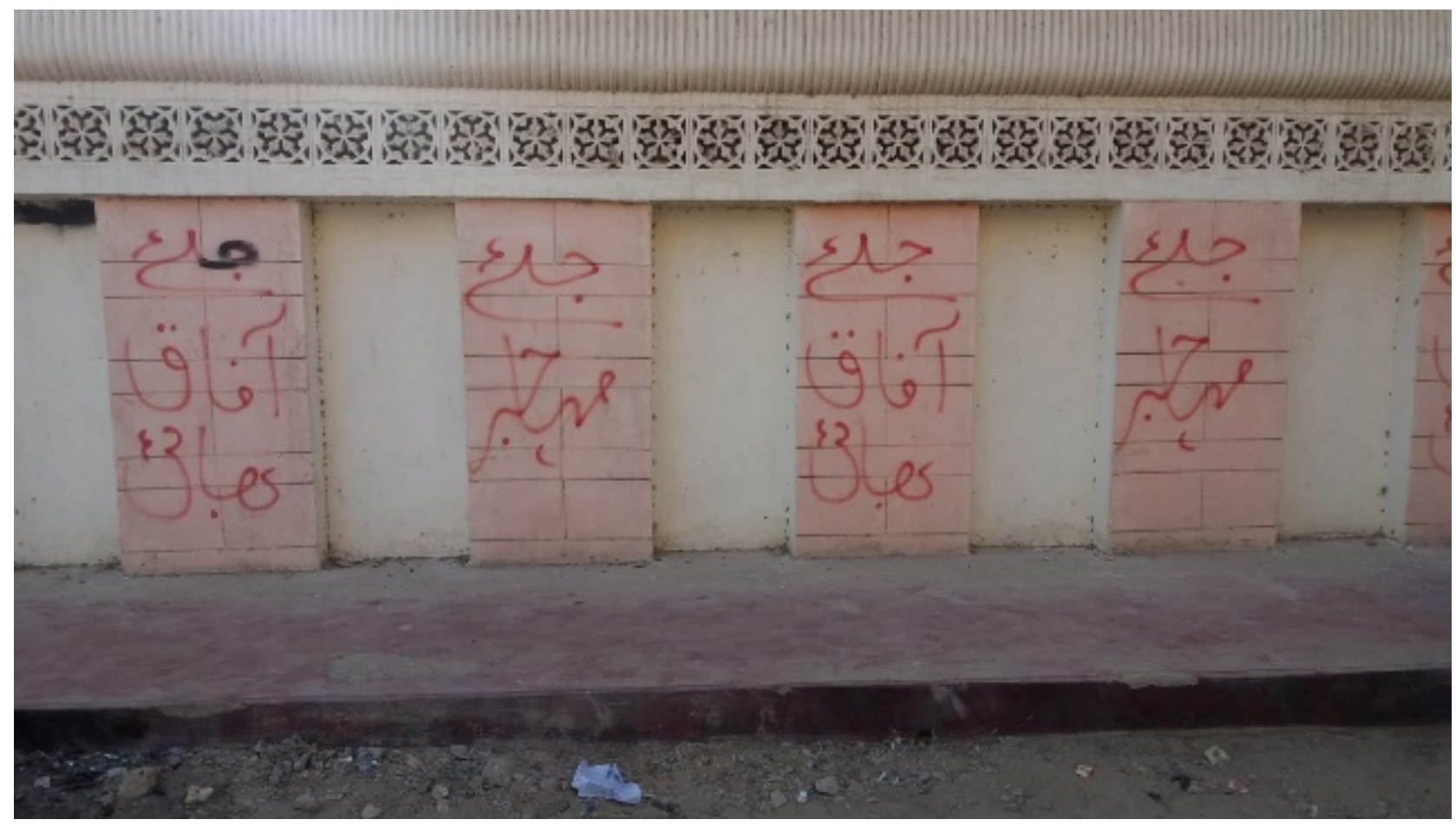

Figure 9: Another wall in Shah Faisal Colony showcasing slogans in favor of MQM. Source: Authors 